\title{
Analysis of Students Misconception in Completing Mathematical Questions Using Certainty of Response Index (CRI)
}

\author{
Elsa Meriani Waluyo, Arif Muchyidin*, Hadi Kusmanto \\ Faculty of Education and Teacher Training, IAIN Syekh Nurjati Cirebon, Indonesia
}

\section{Article History: \\ Received: September $18^{\text {th }}, 2018$ \\ Revised: Januari $25^{\text {th }}, 2019$ \\ Accepted: June $15^{\text {th }}, 2019$ \\ Published: June $24^{\text {th }}, 2019$}

\section{$\overline{\text { Keywords: }}$}

Certainty of Response Index (CRI),

Misconceptions,

Tangent circle.

\section{*Correspondence Address:} muchyidin@syekhnurjati.ac.id

\begin{abstract}
The misconception is a notion of an understanding that is inconsistent with a scientific notion or an interpretation of the relationship of unacceptable concepts. This study conducted to identify the misconception of students of class VIII MTs Negeri 9 Cirebon on the concept of a tangent circle. The research method used is a mixed method. Sampling using random sampling, so that obtained 48 student samples. The instruments used in this study were multiple choice objective tests accompanied by Certainty of Response Index (CRI) method and diagnosis interview. Based on its completeness, the analysis shows that misconceptions appear on sub concepts tangent of the circle of $34,5 \%$, a tangent to two circles of $35,6 \%$, an outer circle and an inner circle of the triangle of $33,3 \%$. On average misconceptions that occur in students that are at sub concepts, tangent two circles on about ten percentage are $43,8 \%$. This analysis shows that misconceptions in the student because students do not understand the concept fully and connecting one concept to another with partial understanding, resulting in the student, makes the wrong conclusions. Based on analysis of these data showed that the CRI effectively used to determine the misconceptions and effective diagnostic interview used in knowing the reason students are causing students had misconceptions.
\end{abstract}

\section{INTRODUCTION}

Mathematics is one field of study that occupies an important role in education. Mathematics is a universal science that underlies the development of modern technology, advances human thinking and has an important role in education. Besides, that mathematics is a special science, has a systematic, organized order, which studies numbers, logic, space, form, calculation, and reasoning. Mathematics is also one subject that is not easy to be conquered by some students compared to other subjects. Because in addition to students must be able to develop strength in its calculations, students are also required to understand operations and concepts that are arranged systematically, hierarchically, and logically from simple concepts to complex concepts, from concrete concepts to abstract concepts (Diani, Latifah, Anggraeni, \& Fujiani, 2018).

Understanding of concepts is an important competency in learning mathematics. Mastery of many concepts in mathematics allows learning mathematics to be able to find solutions to problems better. This can happen because learning mathematics must deal with rules in the form of axioms, definitions, theorems, formulas or algorithms. All of these rules are based on interrelated 
concepts. Learning mathematics can master the subsequent concepts in mathematics if the underlying concepts have been mastered.

In a learning activity, there are often various kinds of obstacles that make learning and teaching activities disruptive. One of the obstacles that occur in the learning process is that the concepts conveyed by the teacher cannot be accepted by students well or often called misconceptions. According to Suparno (2005), the misconceptions that students have can also come from the initial knowledge (preconception) that they had before through their own life experiences, which were formed because of the incomplete information they received before (Ausubel, 2000; Suparno, 2005).

A Misconceptions experienced by each student in a class can be different from different causes. Therefore, it is very important for teachers to recognize misconceptions and their causes that occur in students (Mahendrawan, 2012). A misconception in mathematics can be a serious problem if it is not immediately corrected because the fault of one concept can lead a student to a continual error. Because a basic concept in mathematics will continue to be applied further materiality. Learning that does not consider students 'initial knowledge results in students' misconceptions becoming more complex and stable. The misconception is seen as an important inhibiting factor for students and referrals for teachers in learning and teaching science. Misconceptions in students that appear continuously can interfere with the formation of scientific conceptions. Learning that does not pay attention to misconceptions causes learning difficulties and eventually will lead to low learning achievement.

Erroneous concept change is one form of achieving conception that is appropriate with the experts and eliminating the misconceptions that become obstacles in the student learning process. The things that led to a change in concept according to Hashweh (Hashweh, 1986) include: the first is the teacher who is unaware of the preconceptions that students have. Second, the evaluation method used by the teacher fails to test the concept that is owned by the student which turns out to show the wrong answer. Third, teachers generally are not critical of the answers given by students which indicate a false preconception. Therefore, to be able to help a teacher in overcoming the wrong preconceptions possessed by students, it is necessary to have a diagnostic test that can measure misconceptions or misconceptions that students have.

Kriswanto (2013) states that there are three types of misconceptions when students study the tangent material of the circle, namely misconceptions of classification, correlational, and theoretical (Kriswanto, 2013). The misconception of classification generally occurs when students are wrong in defining circles, tangents of circles and elements contained in a circle. Meanwhile, the concept of correlational errors occurs when students wrongly determine the relationship of a concept with other concepts, as well as the relationship between the formula and the process of its completion. While theoretical concept errors occur when students are wrong in explaining the facts related to the tangent material of the circle.

The tangent circle is a concept from the field of geometry. The connection between concepts in geometry is very close, making some things need to be known by students before students learn the concept of tangents of the circle including that students must first understand the concept of circles and their properties, concepts of lines, as well as Pythagoras theorems. If the initial concepts which are the prerequisites of a geometric concept have not been 
understood, it is certain that students are not able to understand the concept.

Based on the observations made in MTsN 9 Cirebon, in class VIII considered tangents of circles are one concept that is not easy for students to understand, this is evidenced by about $78.37 \%$ of students get low scores with a passing grade of 70 . From the interview conducted by researchers with students and teachers that researchers obtain information that students have difficulty in learning the concept of tangent circles that is one of the material that is still less controlled by students. In the tangent material, there are still students who are wrong in working on the problem. This is because the material for elementary school is limited to understanding the properties of the circle, measuring the diameter and area of the circle. While at the junior high school level the level of difficulty is relatively higher with the subject tangent of the circle. The high level of difficulty is indicated by the many mistakes made by students in solving questions about the tangent of the circle and some students only memorize formulas without understanding the concept.

In expressing students' misconceptions it is necessary to have an efficient test, namely by providing a diagnostic test. According to Arikunto (2012), a diagnostic test is a test that is used to determine students' weaknesses so that based on these weaknesses can be given the right treatment (Suharsimi Arikunto, 2010). Diagnostic tests capture information about why students answer incorrectly on the problem. Attention is more focused on the wrong answer and the effort to find the causes of the student to give the wrong answer. In analyzing the misconceptions experienced by students, a teacher can provide various types of tests that can determine the location of students' misconceptions. The types of tests that can be used to analyze concept errors experienced by students that are often used by researchers and teachers according to Suparno (2005), include: concept maps (concept mars), CRI methods, multiple choices (Multiple Choice Test) with reasoning open, written essay test, diagnostic interview, discussion in class, practicum with question and answer.

In this study, misconceptions will be identified based on the students' level of confidence using the Certainty of Response Index (CRI) method. This method was introduced by Saleem Hasan, Diola Bagayoko, and Ella L. Research conducted aimed to distinguish between students who experienced misconceptions and did not understand the concept quite difficult (Palinggi, 2016). Therefore they make methods to differentiate the two (misconceptions and not understand concepts).

This CRI method has advantages and disadvantages. The advantage is that it is simple and can be used at various levels (high school to college), while the weakness is that this method is very dependent on the honesty of students. In this study to support the CRI method, the diagnosis interview method was used to determine the consistency of each student who was diagnosed as having an answer to the misconception at CRI. With the interview method, the reasons for the students' misconceptions can be explored further. So that researchers can obtain information objectively.

On the other hand, the CRI method has weaknesses, namely the categorization of the level of understanding of students have a low level of confidence and the magnitude of the student's guessing factor in answering question because the form of the question used is a test multiple-choice (Mustaqim, Zulfiani, \& Herlanti, 2014). 


\section{THEORETICAL SUPPORT}

The concept is a very important thing and becomes the basis of a learning process in the classroom, without a concept, a student will experience difficulties in solving various problems (Tristanti, 2017). The difficulties are usually because students do not understand or can not relate the concept of one with the other concepts (Mutia, 2017). Some teachers usually give concepts to students by giving some examples of questions so that students can solve problems that are in accordance with the mathematical formula previously taught without them understanding and knowing what concept is behind the problem.

In giving concepts to students so they can understand the concepts described, the teacher should be able to follow the three rules put forward by Tennyson, et al (Tennyson, Woolley, \& Merrill, 1972) and Houtz et al (Houtz, Moore, \& Davis, 1973), as for the three rules, among others: when in the learning process a teacher should provide an example from easy to difficult, the example given must be different from the others and can compare and distinguish each of the examples. By following these three rules, it is expected that students can obtain concepts that are in accordance with scientific concepts.

A concept is an unit of meaning that represents a number of objects that have identical or similar characteristics (Djamarah, 2011; Mutia, 2017; Sagala, 2011). According to Slavin (2011), the concept is generally studied in two ways, namely (Slavin, 2011):

1. Observation Method

Generally, the concept in this way is studied non-formally. For example, children learn the concept of "cars" by looking at certain vehicles called "cars". At first, the child might include a motorcycle in the concept of "car" but, after time has passed, the concept is improved so that the child can clearly distinguish "car" from "not car".

2. How to Definition

A concept that can only be interpreted correctly by means of defining, for example, to be an aunt, someone must be a woman whose brother or sister (or brother-in-law or daughter-in-law) has children not by observing women who are called aunts. Based on this definition, examples and not examples of "aunts" can be distinguished quickly.

According to Suparno (2013) misconception is a concept that is not in accordance with scientific understanding or understanding received by experts in that field. In the sense of Ormrod (Ormrod, 2009) states that misconception is a belief that is not in accordance with the generally accepted explanation and indeed has been proven valid about something. Meanwhile, according to Istiyani et al (Istiyani, Muchyidin, \& Raharjo, 2018), misconceptions are students' understanding that is not in accordance with the concepts used by experts. From some of the above meanings, it can be concluded that misconception is an idea of an understanding that is not in accordance with scientific understanding.

This Certainty of Response Index method is a method introduced by Hasan et al (Hasan, Bagayoko, \& Kelley, 1999b) which is used to measure misconceptions. With the CRI method, respondents are asked to provide a level of certainty of their own ability by associating the level of confidence with knowledge, concepts, or the law.

This CRI method asks the respondent to answer questions accompanied by giving the degree or scale of the respondent's confidence in answering the question. So this method can describe students' beliefs about the truth of alternative answers that are responded to. Tabel 1 show that the 
response scale of Certainty of Response Index (Liliawati \& Ramalis, 2009).

Table 1. Response Scale of Certainty of Response Index (CRI)

\begin{tabular}{|c|c|c|c|}
\hline \multirow{2}{*}{ CRI } & \multirow{2}{*}{ Criteria } & \multicolumn{2}{|c|}{ Category } \\
\hline & & $\mathbf{T}$ & $\mathbf{F}$ \\
\hline & $\begin{array}{ll}\text { Totally } & \text { Guessed }\end{array}$ & & \\
\hline 0 & $\begin{array}{ll}\text { Answer): If in } & \text { If } \\
\text { answering } & \text { questions }\end{array}$ & DU & DU \\
\hline 1 & $\begin{array}{l}\text { (Almost Gues): If in } \\
\text { answering the question } \\
\text { the percentage of the } \\
\text { element of guess is } \\
\text { between } 75-99 \% \text {. }\end{array}$ & DU & DU \\
\hline 2 & $\begin{array}{l}\text { (Not Sure): If in } \\
\text { answering the question } \\
\text { the percentage of the } \\
\text { element of guess is } \\
\text { between } 50-74 \% \text {. }\end{array}$ & DU & DU \\
\hline 3 & $\begin{array}{l}\text { (Sure): If in answering } \\
\text { questions about the } \\
\text { percentage of elements } \\
\text { guessed between 25- } \\
49 \% \text {. }\end{array}$ & $\mathrm{U}$ & M \\
\hline 4 & $\begin{array}{l}\text { (Almost certain): If in } \\
\text { answering questions the } \\
\text { percentage of elements } \\
\text { guessed between 1- } \\
24 \% \text {. }\end{array}$ & $\mathrm{U}$ & M \\
\hline 5 & $\begin{array}{l}\text { (Certain) If in } \\
\text { answering questions } \\
\text { there is no element of } \\
\text { guessing at all }(0 \%) \text {. }\end{array}$ & $\mathrm{U}$ & M \\
\hline$* \mathrm{DU}$ & $=$ Do not understand & & \\
\hline *U & $=$ understand & & \\
\hline$* \mathrm{M}$ & $=$ Misconception & & \\
\hline
\end{tabular}

Based on Table 1, there are $6(0-5)$ CRI scales where 0 means that they do not understand the concept and 5 are true of the concept that respondents answered. If the confidence level is low (CRI value $0-2$ ) states that the respondent answers it by guessing, regardless of the answer is right or wrong. This shows that respondents do not understand the concept. If the CRI value is high, and the answer is correct then it indicates that the respondent understands the concept (the answer is reasonable) If the CRI value is high, the answer is wrong then shows misconceptions. So, a student experiences misconceptions or does not understand the concept can be distinguished in a simple way that is by comparing the correct or not the answer to a problem with the high and low certainty of the answer index (CRI) given to the problem. Next, Table 2 describes the provisions for distinguishing between students who know concepts, misconceptions, and do not understand the concepts for individual and group respondents.

Table 2. Provisions to Distinguish between Know Concept, Misconception and Don't Know the Concept for Respondents

\begin{tabular}{|c|c|c|}
\hline $\begin{array}{l}\text { Answer } \\
\text { Criteria }\end{array}$ & $\begin{array}{c}\text { Low CRI } \\
(0-2)\end{array}$ & $\begin{array}{c}\text { High CRI } \\
(3-5)\end{array}$ \\
\hline $\begin{array}{l}\text { Correct } \\
\text { answer }\end{array}$ & $\begin{array}{l}\text { The answer is } \\
\text { correct but low } \\
\text { CRI means not } \\
\text { knowing the } \\
\text { concept (lucky } \\
\text { guess). }\end{array}$ & $\begin{array}{l}\text { Right answer } \\
\text { and high CRI } \\
\text { means } \\
\text { mastering the } \\
\text { concept well. }\end{array}$ \\
\hline $\begin{array}{l}\text { Wrong } \\
\text { answer }\end{array}$ & $\begin{array}{l}\text { The wrong } \\
\text { answers and low } \\
\text { CRI means not } \\
\text { knowing the } \\
\text { concept. }\end{array}$ & $\begin{array}{l}\text { The wrong } \\
\text { answer but high } \\
\text { CRI means a } \\
\text { misconception. }\end{array}$ \\
\hline
\end{tabular}

From the tabulation of each student's data by referring to a combination of the right and wrong answers and based on the high and low CRI scores, then the diagnosis data are grouped into three groups: students who understand the material, misconceptions and do not understand. The CRI method functions based on Saleem's research (Hasan, Bagayoko, \& Kelley, 1999a), namely:

1. The tool assesses the appropriateness/ suitability of the emphasis on a concept in several sessions.

2. A diagnostic tool that allows teachers to modify the way they are taught

3. A tool for evaluating the content of the progress/ the extent of effective teaching.

4. Tools compare the effectiveness of a learning method including technology, strategy. the approach integrated into it. Is able to improve understanding 
and increase students' skills in solving problems.

\section{METHOD}

According to Sugiyono (Sugiyono, 2015), the research method is basically a scientific way to obtain knowledge or to obtain a data with a specific purpose and purpose, in a systematic way according to the rules of a study. Judging from the purpose of this study, which is to investigate the condition of students 'misconceptions by using the Certainty of Response Index (CRI) in order to obtain clear information or descriptions of students' misconceptions, this research uses mixed methods. Mixed methods research design (mixed methods research design) is a procedure to collect, analyze, "and mix" quantitative and qualitative methods in research or series of studies to understand research problems (Creswell, 2013).

Researchers determine which schools will be used as research sites. The target population used in this study were all students of MTs Negeri 9 Cirebon (Islamic Junior High School) as the place of research while the population in this study were all students of class VIII totaling 319 students.

The sampling technique used is random sampling technique which is a sampling technique where all individuals in the population either individually or together are given the same opportunity to be selected as sample members. The sampling method used in this study is the lottery method, namely sampling by giving an opportunity to each individual to become a member of the sample. In the instrument test sample collection was carried out in class VIII D as many as 44 students. While the sample of objective test data retrieval and diagnostic interviews were carried out in class VIII $\mathrm{C}$ as many as 48 students who had obtained the concept of a tangent circle.

The instruments used in this study are using tests and nontest. For tests in the form of objective tests, while for nontest using the diagnosis interview method. The results of objective test data supplemented by CRI and interviews were then analyzed, and divided into two categories, namely quantitative and qualitative data. In descriptive research, quantitative data is data in the form of numbers and qualitative data expressed in the form of words or symbols (S Arikunto, 2012).

The discussion is carried out by analyzing the objective test results items which are complemented by the CRI method in each sub-concept which has a high percentage of misconceptions in students, then supported by the decision of CRI value combination data for wrong answers (CRI) and fractions (F) per item and associated with the results of diagnosis interviews in students. The results of the percentage of misconceptions were misconceptions sought to be analyzed by diagnosis interview. Data on misconceptions and interview results are interpreted to determine the causes of misconceptions.

The equation to look for the percentage of students in answering questions and their level of belief into a group of understanding, misconceptions, and not understanding the concept and in determining the questions that are categorized as misconceptions and do not understand the concept are as follows (Sudijono, 2010):

$$
P=\frac{f}{N} x 100 \%
$$

To distinguish between students who experience misconceptions and students who do not understand the concept in each item, the data analysis uses fraction value $(\mathrm{F})$ combined with CRI values for wrong answers (CRI) in each question. The fraction is used to distinguish between questions that are not understood and questions that are perceived by students as a whole or 
group. To search for CRI, and fractions can use the following formula (Sudijono, 2010).

$$
\begin{gathered}
\text { The CRIs }=\frac{\sum C R I \text { value that answers incorrect }}{\sum \text { students who answer wrong }} \\
F=\frac{\sum \text { students answer correctly }}{\sum \text { students }}
\end{gathered}
$$

The provisions for knowing the CRI value for wrong answers (CRI) and fractions per item based on the summary of the journal and the summary of the results of the author's interview, in addition to using the provisions in Table 2 , when trying to find out the questions with students' conceptual categories and not comprehended comprehensively, it is necessary fraction provisions in the Table 3.

Table 3. Provisions of the Combination of CRI and Faction Value

\begin{tabular}{ccc}
\hline Fraction & CRI & Conclusion \\
\hline$>0.5$ & $2-3$ & $\begin{array}{c}\text { Don't understand the } \\
\text { concept } \\
\end{array}$ \\
$=0.5$ & $2-3$ & Neutral \\
$<0.5$ & $2-3$ & Misconception \\
\hline
\end{tabular}

\section{RESULT AND DISCUSSION}

Based on the results of objective test data using the Certainty of the Response Index method in Table 3 shows that there are still many students who experience misconceptions. The following data tabulation of students understand, misconceptions, and do not understand the concept. In the tangent sub-concept, the number of students experiencing misconceptions at number 3,4 and 7 is $37.5 \%, 39.6 \%$, and $37.5 \%$. In the tangent sub concepts, two circles number 8,10 , 11 , and 14 have a high percentage of misconceptions, namely $41.7 \%, 43.8 \%$, $39.6 \%$, and $39.6 \%$. While at number 16 with a percentage of $37.5 \%$ is a question item with a percentage of the misconception that is quite high in the sub-concept of the outer circle and the inner circle of the triangle.

Based on the results of the research data shows that the CRI method is effective for analyzing students who experience misconceptions. As for the grouping, the level of students' understanding is analyzed based on the level of student understanding individually and the level of students' understanding in groups. Students experience misconceptions or do not understand the concept can be distinguished by seeing whether or not the answer to an item is correct and seeing the high or low answer certainty index (CRI) that the student provides so as to produce data on the percentage of students based on answers and index (CRI) in the category of understanding, misconception, do not understand the concept. Data from the results of the analysis can be used to obtain further diagnosis interview data. To find out the items that are disconcepted by students and not understood by students can be known by calculating the CRI value for the wrong answer then combined with the fraction values which can be seen in table 4.

The percentage of students who understand the concept, misconceptions, and do not understand the concepts in each item tested in Table 3 shows that of the 17 questions each concept still has a lot of students' misconceptions and many students understand, while students who do not understand the concept few in number. Table 4 shows the dominant problems in understanding concepts, not understanding concepts, and misconceptions.

Table 4. Concept Understanding Group, No Concept Understanding, and Misconception

\begin{tabular}{cc}
\hline Category & Number \\
\hline $\begin{array}{c}\text { Understand the } \\
\text { Concept } \\
\text { Misconception } \\
\text { Don't understand the } \\
\text { concept }\end{array}$ & $1,2,5,6,12,13,15$ \\
\hline
\end{tabular}


Based on the Table 4 questions that show the high percentage of students understand the concept is at number 1 that is equal to $47.9 \%$. The concept that shows students experiencing misconceptions with a high percentage is in number 10 , namely the percentage of $43.8 \%$, while the questions that are not understood by students are number 9 with a percentage of $41.7 \%$.

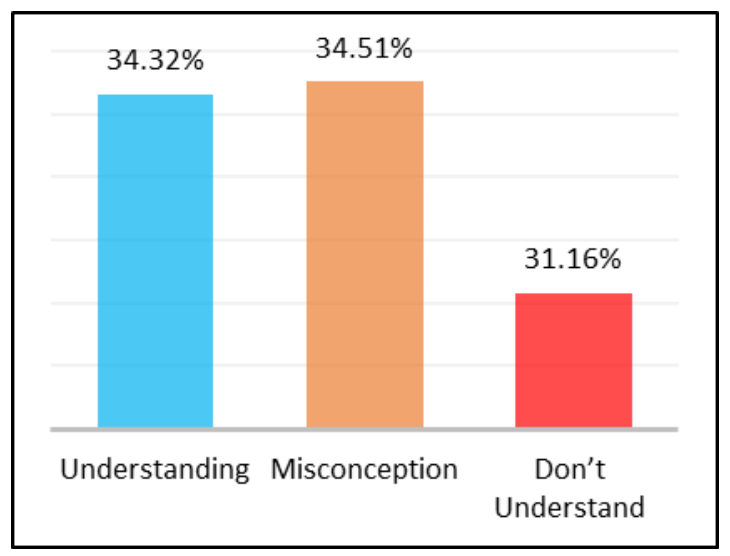

Figure 1. Graph of Percentage of Students' Understanding Level on the Concept of Tangent Lines
Figure 1 shows the average percentage of students understanding concepts, misconceptions, and not understanding the concept of tangent circles. The high percentage of students understanding concepts, misconceptions, and not understanding the concept of tangent circles. From the graph, it can be seen that $34.32 \%$ on average students understand the concept of tangent circles, $34.51 \%$ on average students misconceptions about the concept of tangent circles, $31.16 \%$ on average students do not understand the concept of tangents circle.

Figure 2 shows the value of CRI (CRI for wrong answers) per item related to the fraction (number of students who answered correctly) on the concept of tangent circles. The purpose of the graph is made to make it easier to see items that are not understood and the items that are conceptualized by students.

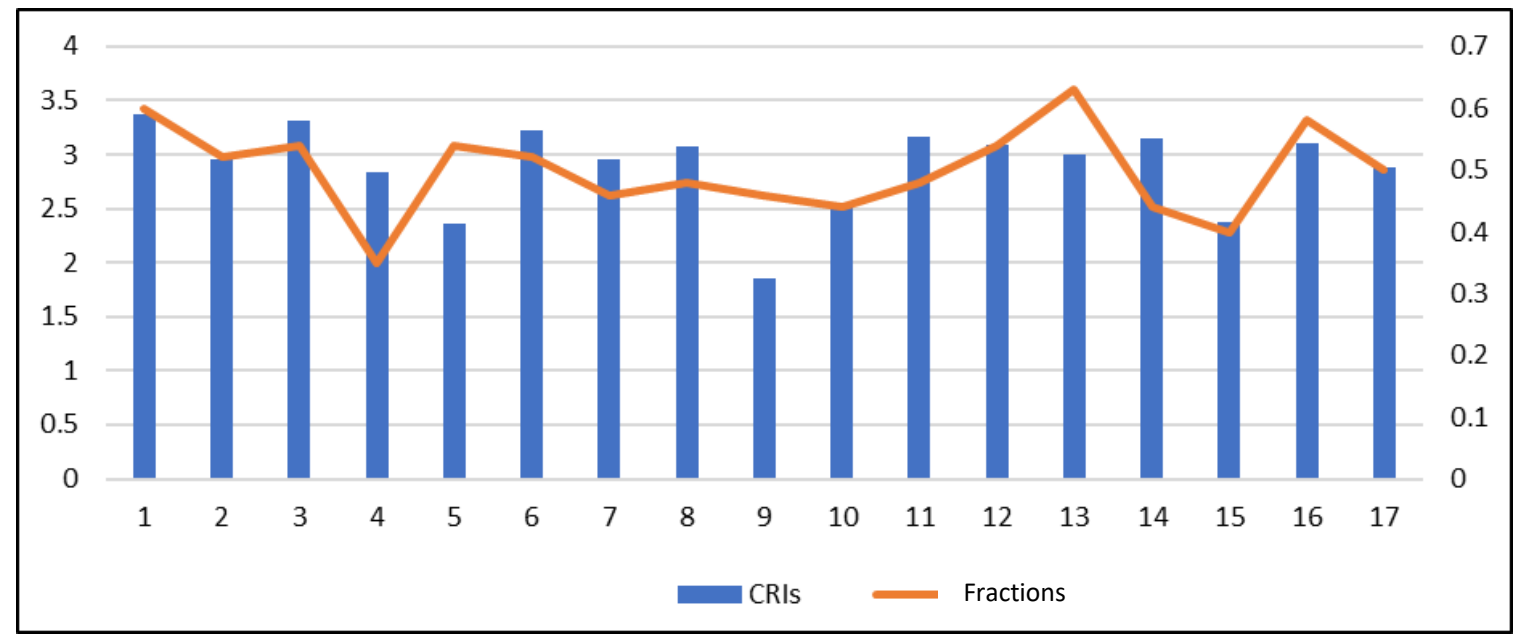

Figure 2. Graph of CRI Values for Wrong Answers and Fractions (F) on Concept of Tangent Circles

Hasan, et al. (Hasan et al., 1999b) use a threshold line at 2.5 as a determinant of high or low CRI values. As in Table 3, the CRI value above or below the 2.5 thresholds is considered using the number of fractions. The threshold is intended to determine one possibility (high or low) in a zone that cannot be determined, namely the range of numbers 2-3.

In question number 5 the CRI value is 2.36 (CRI < 2.5) with a fraction value of 0.54 this indicates that students tend to have low confidence in answering the question or not understanding the concept. This was supported by the large number 
of students who answered correctly, namely 26 students or $0.54 \%$. This shows that only $0.46 \%$ of students who have difficulty answering questions number 5 . So it can be decided that in this number students do not understand the concept.

In question number 9, the CRI value is 1.85 and the fraction value is 0.46 . Based on Table 4, the number is included in the wrong low category or does not understand the concept. This shows that only a small percentage of students experience difficulties (misconceptions) in answering number three, this is probably due to the lack of understanding of the concepts in students.

Question number 15, the CRI value is 2.38 with a fraction value of 0.4 . As described in the previous paragraph. CRI in this number is in zones 2-3. Based on the 2.5 thresholds and the fraction value of 29 students or $0.60 \%$ students answered correctly. On the contrary, 0.39 $\%$ or only 19 students had difficulties in answering questions. This indicates that students tend to not understand the concept.

At number 4, the CRI value is 2.84 with a fraction of 0.35 . Based on the 2.5 thresholds and the fraction value of 0.35 $\%$ or only 17 out of 48 students answered correctly. In this number the student CRI is said to be relatively high because the number of students who answered correctly was very low, it indicated that students tend to misconceptions.

In question number 10 , the CRI value is 2.56 with a fraction of 0.44 . This indicates that students tend to misconceptions because the CRI value in this number is in zones 2-3, based on 2.5 thresholds and fractions of 21 students or $0.44 \%$ of students answer correctly. In contrast $0.56 \%$ or as many as 27 students who had difficulty answering questions.

Based on the explanation, each item can be categorized into two groups, namely students' misconception items and items that are not understood by students.
The data recapitulation can be seen in Table 5.

Table 5. Recapitulation of Question Points on Misconception Categories and Not Understanding Concepts Based on CRI and F Values

\begin{tabular}{cc}
\hline Category & Number \\
\hline Misconception & $1,2,3,4,6,7,8,10$, \\
& $11,12,13,14,16,17$ \\
$\begin{array}{c}\text { Don't understand the } \\
\text { concept }\end{array}$ & $5,9,15$ \\
\hline
\end{tabular}

After knowing the grouping of students' level of understanding through objective tests using CRI as many as 17 questions, it can be known to students who experience misconceptions. Furthermore, the researcher conducted an interview phase for students who identified misconceptions to find out the reasons for students so they experienced misconceptions about the concept of tangent circles. The highest percentage of students' misconceptions was obtained at number 10 , which was $43.8 \%$, and the lowest misconception was obtained at number 5, which was $22.9 \%$.

The results of the interview were as follows: To find out the students' understanding of the concept of tangents the circle is used questions number 1,2 , $3,4,5,6$, and 7 . The highest percentage of students' misconceptions is obtained at number 4 , which is $39.6 \%$.

4. Consider the following picture:

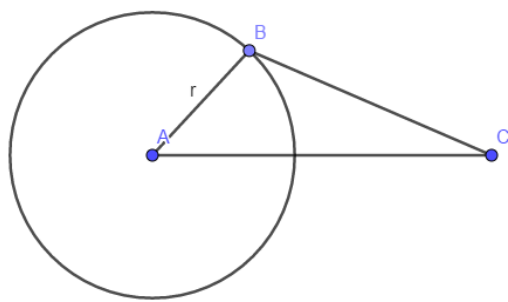

In the picture above, the line $\mathrm{BC}$ is the tangent of a circle through point $\mathrm{B}$ outside a circle of $20 \mathrm{~cm}$ with a distance $\mathrm{AB}=16$ $\mathrm{cm}$, then the radius $\mathrm{AB}$ is ...

Figure 3. Test Question Number 4 
In question number 4 students are asked to determine the radius of the OA circle. This problem is the number most widely disconcepted by students, with a percentage of $39.6 \%$, this is also supported by the low fraction of 0.35 or only 17 of 48 students who can answer the question correctly. In addition, when searching for CRI in this number, a value of 2.84 (> 2.5) is obtained so that it can be concluded that this number is a number that isa misconceptionby students.

Based on the analysis of objective test results and student interviews that the researcher did, Interviewee 11 chose answer B (-12). The reason for choosing this answer is because the calculation feels confident and correct seen from the CRI value of 4 (almost correct). From the results of interviews and tests, students still make a lot of mistakes in algebraic operations such as addition and how to move the segment from the previous calculation results. From the results of interviews and tests, students still make a lot of mistakes in algebraic operations such as addition and how to move the segment from the previous calculation results. Probably this is because students do not really understand in the form of algebra, how to move the operational area from left to right or right to left, positive negative, reduction in sum.

Excerpt from the interview above shows that students are wrong in applying the Pythhorhoras formula, students already know that the problem can be solved by the Pythagoras formula, but students are wrong in applying it. This is because students do it just simply answering it less thoroughly in applying it to the Pythagoras formula, not knowing the concept. In addition, students also make mistakes in the calculation process. Students do not apply the calculation of $A B$ length even though the length of $A B$ is known so that students are wrong in solving it.

To find out the students' understanding of the two-circle tangent sub-concept question number $8,9,10,11$, $12,13,14$, and 15 . The highest percentage of students' misconceptions was obtained at number 10 , which was $43.8 \%$.

10. The radius of the two circles is $2 \mathrm{~cm}$ and $10 \mathrm{~cm}$, respectively. The length of the outer tangent line is $15 \mathrm{~cm}$. The distance between the two center points of the circle is ...
a. $9 \mathrm{~cm}$
c. $19 \mathrm{~cm}$
b. $17 \mathrm{~cm}$
d. $7 \mathrm{~cm}$

Figure 4. Test Question Number 10

In question number 10 students are asked to determine the length of the tangent to the alliance outside the two circles. This problem is the number that is the most discretionary of students, namely the percentage of $43.8 \%$, this is also supported by the low fraction of 0.44 or only 21 of 48 students who can answer the question correctly. In addition, when the CRI is searched for in this number, a value of $2.56(>2.5)$ is obtained so that it can be concluded that this number is a number that is a misconception by students.

Based on the analysis of objective test results and student interviews conducted by the researcher, interviewee 7 chose the answer D $(7 \mathrm{~cm})$. The reason for choosing the answer is because the calculation feels confident and correct seen from the CRI value of 5 (true).

From the excerpts of the interview it can be seen that the students' answers are mistaken in using the formula to find the distance of the center of the two circles and what is known in the problem is the length of tangency of the two outer circles, in the interview above students feel that the formula used is a formula to find the distance of the center point of the two circles that use the long formula tangent of the alliance outside the two circles, but in the concept the formula used by students is the formula to find the length of the tangent of the alliance in the two circles. This is because students 
misconstrue in recognizing which formula should be used to find the distance of the center of the two circles using the tangent formula of the partnership outside the two circles,

$$
\left(l=\sqrt{k^{2}-(R-r)^{2}}\right)
$$

as well as alliances in both circles,

$$
\left(d=\sqrt{k^{2}-(R+r)^{2}}\right) \text {. }
$$

To find out the students' understanding of the concept circle tangent sub-concepts used questions number 16 and 17 . The highest percentage of students' misconceptions was obtained at number 16 , which was $37.5 \%$.

16.

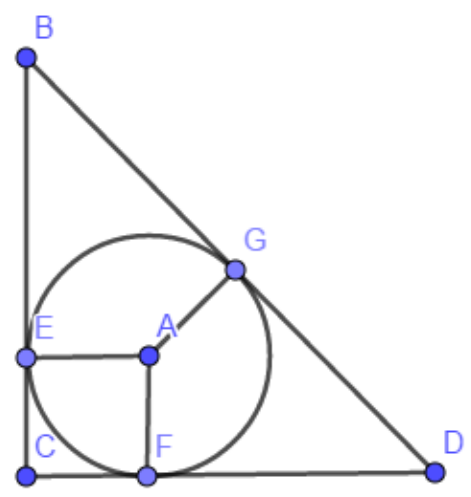

In the picture above, the circle centered on $\mathrm{A}$ is the inner circle $\triangle \mathrm{BCD}$. If the length of $\mathrm{CD}$ $=3 \mathrm{~cm}, \mathrm{BC}=4 \mathrm{~cm}$, and $\triangle \mathrm{BCD}$ right angle in $\mathrm{C}$, specify the length of the radius of the circle $\triangle \mathrm{BCD}$ !

Figure 5. Test Question Number 16

In question number 16 students are asked to determine the radius of the inner circle $\triangle \mathrm{ABC}$. This problem is the number that is themostmisconception by students, with a percentage of $37.5 \%$, this is also supported by a fraction of 0.58 or only 28 of 48 students who can answer the question correctly. In addition, when the CRI is searched for in this number, a value of $3.1(>2.5)$ is obtained so that it can be concluded that this number is a number that is a misconception by students.

Based on the analysis of the objective test results and the student interviews that the researcher did, interviewee 36 chose the answer D (7 $\mathrm{cm})$. The reason for choosing the answer is because the calculation feels confident and correct seen from the CRI value of 5 (true).

The excerpt of the interview can be seen that the students' answers are wrong in applying the Pythagoras formula in solving the problem, and students think that the height of the triangle means the longest side, the length of the $\mathrm{BC}$ side. The reason is that students misconstrued in applying the Pythagoras formula, and misconceptions in determining the height of the triangle.

From the results of misconception analysis that occurs in these students, it can be concluded that students still understand the concept partially or not intact. Partial understanding of students causes students not to provide complete reasons. In addition, some students are still wrong in interpreting the term in the concept of tangent circles where for one thing the same is considered different by students because there are terms in other concepts that are considered not related.

In this study students generally experience misconceptions caused by associative thinking, incomplete or inappropriate reasoning, using the wrong student experience as a conception, and making conclusions based on what appears. So it can be said that students still do not understand the concept as a whole or incomplete.

Piaget (Long, 2000) in cognitive theory states that students who are still in the concrete stage will still be limited in constructing their knowledge, especially in abstract concepts. Students cannot easily generalize, abstract, and logical systematic thinking. In this stage, students' conceptions are incomplete or 
even misconstrued. Meanwhile, according to Comins (Suparno, 2013), students' incomplete reasoning is caused by incomplete information or data, as a result, students draw conclusions incorrectly and this can lead to misconceptions among students. The explanation above proves that effective diagnosis interviews are used to support the CRI method in analyzing misconceptions that occur in students.

\section{CONCLUSION}

Based on the results of data analysis and discussion it can be concluded that misconceptions are still found in the concept of tangent circles, which include tangents of one circle on average by 34.5 $\%$, tangents of two circles on average by $35.6 \%$, and outer circles and the inner circle of the triangle is an average of 33.3 $\%$. The average misconception that occurs in students is the tangent of two circles in the problem of number ten, the percentage is $43.8 \%$, which means that 21 students experience misconceptions about the problem. Whereas based on the students' reasons on the interview results, the misconception is caused by students mastering the concept of not intact and connecting one concept with another with partial understanding, a partial understanding of students causes students not to provide complete reasons. In addition, some students are still wrong in interpreting the term in the concept of tangent circles where for one thing the same is considered different by students because there are terms in other concepts that are considered not related. so students make the wrong conclusion that students still understand the concept partially or not intact.

\section{REFERENCES}

Arikunto, S. (2010). Prosedur Penelitian Suatu Pendekatan Praktik. Jakarta: Rineka Cipta.

Arikunto, S. (2012). Dasar-Dasar Evaluasi Pendidikan (2nd ed.).
Jakarta: Bumi Aksara.

Ausubel, D. P. (2000). The Acquisition and Retention of Knowledge: A Cognitive View. Dordrecht: Kluwer Academic Publishers.

Creswell, J. W. (2013). Research Design: Qualitative, Quantitative, and Mixed Methods Approaches. Sage publications.

Diani, R., Latifah, S., Anggraeni, Y. M., \& Fujiani, D. (2018). Physics Learning Based on Virtual Laboratory to Remediate Misconception in Fluid Material. Tadris: Jurnal Keguruan Dan Ilmu Tarbiyah, 3(2), 167-181. https://doi.org/10.24042/tadris.v3i2.3 321

Djamarah, S. B. (2011). Psikologi Belajar (3rd ed.). Jakarta: Rineka Cipta.

Hasan, S., Bagayoko, D., \& Kelley, E. L. (1999a). Misconceptions and the Certainty of Response Index (CRI). Journal of Psychology Education, $V$. Hasan, S., Bagayoko, D., \& Kelley, E. L. (1999b). Misconceptions and the Certainty of Response Misconceptions and the Certainty of Response Index ( CRI ). Journal of Science And Mathematics Education, 34(5), 294-299.

Hashweh, M. (1986). Toward An Explanation of Conceptual Change. European Journal of Science Education, 8(3).

Houtz, J. C., Moore, J. W., \& Davis, J. K. (1973). The Effects of Different Types of Positive and Negative Instances in Concept Learning. In Journal of Education Psychology. Chicago: American Educational Research Association convention.

Istiyani, R., Muchyidin, A., \& Raharjo, H. (2018). Analysis of Student Misconception on Geometry Concepts Using Three-Tier Diagnostic Test. Cakrawala Pendidikan, 37(2).

Kriswanto, A. (2013). Miskonsepsi Siswa dalam Menyelesaikan Soal Materi 
Lingkaran Kelas VIII MTs

Taqwiyatul Wathon. IKIP PGRI

Semarang.

Liliawati, W., \& Ramalis, T. R. (2009). Identifikasi Miskonsepsi Materi IPBA di SMA Dengan Menggunakan CRI (Certainly of Respons Index) Dalam Upaya Perbaikan Urutan Pemberian Materi IPBA Pada KTSP. Prosiding Seminar Nasional Penelitian, Pendidikan, Dan Penerapan MIPA, 159-168.

Long, M. (2000). The Psychology of Education. New York: RoutledgeFalmer.

Mahendrawan, E. (2012). Upaya Meningkatkan Miskonsepsi Siswa Melalui Metode Pembelajaran Delikan (Dengar, Lihat, Kerjakan) Pada Siswa Kelas VIII Semester Genap Smp Muhammadiyah 2 Surakarta. Universitas Muhammadiyah Surakarta.

Mustaqim, T. A., Zulfiani, \& Herlanti, Y. (2014). Identifikasi Miskonsepsi Siswa dengan Menggunakan Metode Certainty of Response Index (CRI) pada Konsep Fotosintesis dan Respirasi Tumbuhan Tri Ade Mustaqim, Zulfiani, Yanti Herlanti. Edusains, 6(2), 146-152. https://doi.org/10.1186/1744-9081-434

Mutia, M. (2017). Analisis Kesulitan Siswa SMP dalam Memahami Konsep Kubus Balok dan Alternatif Pemecahannya. Beta: Jurnal Tadris Matematika, 10(1), 83-102.

Ormrod, J. E. (2009). Psikologi Pendidikan Membantu Siswa Tumbuh dan Berkembang (1st ed.). Jakarta: Erlangga.

Palinggi, Y. (2016). Penentuan Nilai Half Value Layer (HVL) Dari Plate Aluminium Dengan Metode Variasi Ketebalan Filter Menggunakan $\begin{array}{lcc}\text { Pesawat } & \text { Linear } & \text { Accelerator } \\ \text { (LINAC). } & \text { In } & \text { Universitas }\end{array}$

Hasanuddin. Makassar: Universitas Hasanuddin.

Sagala, S. (2011). Konsep dan Makna Pembelajaran. Bandung: Alfabeta.

Slavin, R. E. (2011). Psikologi Pendidikan Teori dan Praktik. Jakarta: PT. Indeks.

Sudijono, A. (2010). Pengantar Statistik Pendidikan (XXII). Jakarta: Rajawali Press.

Sugiyono. (2015). Metode Penelitian Pendidikan Pendekatan Kuantitatif, Kualitatif dan $R \& D$. Bandung: Alfabeta.

Suparno, P. (2005). MIskonsepsi dan Perubahan Konsep Dalam Pendidikan Fisika. Jakarta: Grasindo.

Suparno, P. (2013). Miskonsepsi dan Perubahan Konsep Dalam Pendidikan Fisika. Jakarta: PT. Gramedia Widiasarana Indonesia.

Tennyson, R. D., Woolley, F. R., \& Merrill, M. D. (1972). Exemplar and nonexampler variables which produce correct concept classification behavior and specified classification errors. Journal of Educational Psychology, 63(2), 144152.

Tristanti, L. B. (2017). Pengaruh Model Pembelajaran Kooperatif Tipe TAI Dan Problem Based Learning (PBL) Terhadap Pemahaman Konsep Bangun Ruang Siswa. Jurnal Pendidikan Matematika FKIP Univ. Muhammadiyah Metro, 6(3), 338349. 